Journal of the Scholarship of Teaching and Learning, Vol. 20, No. 1, April 2020, pp.155-157.

doi: $10.14434 /$ josotl.v20i1.24589

\title{
Breaking Through Student Bias with Creative Debate Assignments
}

\author{
Daniel M. Settlage \\ University of Arkansas-Fort Smith \\ dan.settlage@uafs.edu
}

\begin{abstract}
This article outlines a method used to successfully breakthrough student bias surrounding controversial issues in the classroom. The method uses a debate with randomized position assignments to encourage students to consider all sides of the topic. Student feedback is overwhelmingly positive and students appear to develop a newfound respect and deeper understanding of the assigned subject.
\end{abstract}

Keywords: debate, student bias, active learning, cooperative learning

Motivating students to become truly academically engaged with a topic while challenging their preconceived view of the word is a difficult task. Given the increasingly politicized and pundit-filled news cycle, inspiring a deep and critical analysis of both sides of a controversial issue is a challenging, yet vital, endeavor. Student opinions are often shaped more by their parents and peer groups than by a detailed factual analysis of the issues. The rigidity of their opinions frequently persists despite being confronted with additional, and often contrary, factual evidence. In a world full of 'fake news' it is more important than ever to endow our students with key critical thinking skills.

The job of an academic in the classroom is to break through this dogmatism and engage students in a thought process that removes barriers to learning and delves into all facets of a topic. In order to do this, I have experimented with the use of student debates in an upper division natural resource economics class. Debates have a long history of use in an academic setting. Debates as a teaching strategy dates back to ancient times, although modern high school and college students are rarely exposed to debates outside of participation on a debate team (Kennedy, 2007 and Kennedy, 2009). Research on debate as a pedagogical technique focuses on the role debate plays in fostering critical thinking skills in an active learning environment. In the healthcare field, Garrett and Hood (1996), Darby (2007), and Randolph (2007) all find debate as a teaching and learning technique is ranked highly by students. Kennedy (2007 and 2009) finds that debates foster active learning and students report an increase in critical thinking skills following their exposure to debates. Scott (2008) echoes these observations in a technological setting. Very little research has been done regarding debates in an economic setting, with Pernecky (1997) and Vo and Morris (2006) being the lone exceptions. Pernecky (1997) finds that research, written and oral communication, and critical thinking skills are all enhanced by incorporating debates into the economic classroom. Vo and Morris (2006) show that not only do debates engage students via active learning, but students find debate assignments helpful in the process of learning economics.

Natural resource economics is an ideal platform for debates as it is filled with a number of issues for which people often hold strong opinions. Drilling in the Arctic National Wildlife Refuge, delisting gray wolves from the Endangered Species Act, dam removal and habitat restoration on the Snake River in the Columbia River basin, off-highway vehicle use policy on public lands, and the silvicultural practice of clear-cutting on public lands are all controversial and multi-faceted topics that I have explored in this class via student debates.

The assignment I use is a modification of the popular Public Forum Debate, formalized in 2002 (Cossette, 2011). Groups of three or four students are assigned a current topic related to resource economics issues covered in class. Having students debate in teams rather than individuals engages the critical thinking and student learning benefits accorded to cooperative learning assignments (e.g. Slavin, 1996; Johnson and Johnson, 1999; Tsay and Brady, 2010; Yamarik 2007). 
Students are instructed on the format, preparation, and grading rubric for the debate. Over the years, I have experimented with and fine-tuned the debate assignment. I initially assigned positions (either pro or con) by a coin flip on the day of the debate. The intent was to force each team to prepare a case for both sides of the debate, thus making them deeply consider both sides of the issue. To augment this debate preparation, groups were required to submit two graded position papers (both pro and con) with cited sources. These papers formed the foundation of the debate preparation and allowed an opportunity for the instructor to intervene if the group veered off track. The position papers formed a valuable component of the debate assignment, as various viewpoints and the validity of the group's sources could be discussed.

Although this was an effective setup, students balked at the last minute uncertainty regarding their debate positions, and the debates seemed to lack the 'passion' that truly engaged students often exhibit. In an effort to alleviate these issues, I switched to giving teams assigned positions determined by coin flip well before the debate. I continued to require the team pro and con position papers. In addition, I required a one-page bulleted debate plan, which included a summary of the team's main debate points, anticipated rebuttals, and closing debate points. These assignments help nudge students toward creating well-reasoned opening statements, rebuttals, and closing arguments. These changes lead to a more motivated and well-prepared debate experience.

Prior to the debates, class and library time was given for teams to meet and research their topic, both as a team and with the instructor. This allowed the instructor to interact with each team to make sure they were doing the necessary work and to answer any questions they may have. The team/instructor meetings are the perfect venue for the instructor to review the sources of information the team is currently using and to discuss ways of assessing the validity of those sources. Quite frequently, students gravitate towards weak or biased sources of information, and the one-on-one time is invaluable in teaching proper researching techniques.

The debate itself is worth a relatively modest $5 \%$ of the overall course grade. The format consists of an opening statement (two minutes for each team), rebuttal (three minutes for each team), group question and answer session where the class and instructor ask directed questions (three minutes total), and a closing statement (one minute for each team). There are 10 points awarded for each section plus an additional 10 points for full group participation during the debate. This totals 50 points for the assignment in a class with 1,000 possible points.

Not many students show up to a typical class eager to take a test or quiz. On debate day students invariably show up to class professionally dressed, meticulously prepared, excited and motivated. Demonstrated student interest, engagement, and effort expended on this assignment far exceed the 'value' the assignment carries in terms of its contribution to the overall grade in the class. In post-debate debriefs with students, most indicated they entered the assignment with a definite viewpoint regarding the issue they were assigned and fervently hoped they were assigned the side they believed in. After the debates, many students acknowledge they now have a new found understanding of all sides of the issue. By forcing students to examine issues in a critical light, they become more well-rounded and well-reasoned about their own beliefs. Even if their point of view regarding the issue did not change, they still garner both an appreciation of other viewpoints and a factual basis of support for their own position. Although students indicate they were initially very hesitant when first hearing about the debate assignment, they frequently cite the experience as one of the highlights of the course at the end of the semester. In the age of the five second politicized sound bite, it is quite an accomplishment to engage students in such deep level of thought, even if they were 'tricked' into doing it by a combination of a crafty assignment and their own competitive nature. 


\section{References}

Cossette, N.A. (2011). The Art of Debate. (12 th ed.). Lulu.com.

Darby, M. (2007). Debate: A Teaching-Learning Strategy for Developing Competence in Communication and Critical Thinking. Journal of Dental Hygiene, 81(4), 1-12.

Garrett, M, Schoener, L, \& Hood, L. (1996). Debate: A Teaching Strategy to Improve Verbal Communication and Critical-Thinking Skills. Nurse Educator, 21(4), 37-40.

Johnson, D.W., \& Johnson, R.T. (1999). Making cooperative learning work. Theory Into Practice, 38(2), 67-73.

Kennedy, R. (2007). In-Class Debates: Fertile Ground for Active Learning and the Cultivation of Critical Thinking and Oral Communication Skills. International Journal of Teaching and Learning in Higher Education, 19(2), 183-190.

Kennedy, R. (2009). The Power of In-Class Debates. Active Learning in Higher Education 10(3), 225-236.

Pernecky, M. (1997). Debate for the Economics Class-and Others. College Teaching, 45(4), 136-139.

Randolph, D.S. (2007). Student Perceptions of the Use of Debate as a Teaching Strategy in the Allied Health Professions. Journal of Allied Health, 36(1), 13-29.

Scott, S. (2008). Perceptions of Students' Learning Critical Thinking through Debate in a Technology Classroom: A Case Study. Journal of Technological Studies, 34(1), 39-44.

Slavin, R.E. (1996). Research on cooperative learning and achievement: What we know, what we need to know. Contemporary Educational Psychology, 21(1), 43-69.

Tsay, M., \& Brady, M. (2010). A case study of cooperative learning and communication pedagogy: Does Working in Teams Make a Difference? Journal of the Scholarship of Teaching and Learning, 10(2), 78-89.

Vo, H.X. \& Morris, R.L. (2006). Debate as a Tool in Teaching Economics: Rationale, Technique, and Some Evidence, Journal of Education for Business, 81(6), 315-320.

Yamarik, S. (2007). Does Cooperative Learning Improve Student Learning Outcomes? The Journal of Economic Education, 38(3), 259-277. 